Int. J. Electrochem. Sci., 12 (2017) $4183-4192$

International Journal of

ELECTROCHEMICAL

SCIENCE

www.electrochemsci.org

\title{
Electrochemical Impedance Spectroscopy Study on Corrosion Inhibitor for Reinforced Concrete
}

\author{
Daoming Shen ${ }^{*}$
}

School of Civil Engineering and Architecture, Xinxiang University, Xinxiang, 453000, P. R. China *E-mail: shendaoming_xx@163.com

doi: $10.20964 / 2017.05 .38$

Received: 27 January 2017 / Accepted: 17 March 2017 / Published: 12 April 2017

In this essay, electrochemical impedance spectroscopy (EIS) was applied to investigate the behavior of steel at diverse phases during corrosion. The evolution of obtained spectra manifested the start of partial corrosion of steel and the gradual inhibition with different concentrations of the inhibitor. Calcium nitrite was found to have the capacity to inhibit the steel corrosion, and the best inhibitor efficiency was investigated for $\left[\mathrm{Cl}^{-}\right] /\left[\mathrm{NO}_{2}{ }^{-}\right]$. If the value of this rate was attained in the initial phases of the corrosion course, the inhibition efficiency would be higher. Calcium nitrite has excellent effectiveness when used as a penetrating corrosion inhibitor for steel in concrete.

Keywords: Calcium nitrite; Electrochemical impedance spectroscopy; Corrosion inhibitor; Reinforced concrete; Penetration

\section{$\underline{\text { FULL TEXT }}$}

(C) 2017 The Authors. Published by ESG (www.electrochemsci.org). This article is an open access article distributed under the terms and conditions of the Creative Commons Attribution license (http://creativecommons.org/licenses/by/4.0/). 